\title{
Total Sulfur and Ash Yield of Tanjung Formation Coal in Sekako, Barito Basin, Central Kalimantan: Implication of Depositional Process
}

\author{
Beny Wiranata, Hendra Amijaya, Ferian Anggara, Agung Rizki Perdana, Oyinta Fatma \\ Isnadiyati, and Deddy Nan Setya Putra Tanggara \\ Department of Geological Engineering, Faculty of Engineering, Universitas Gadjah Mada, Yogyakarta, Indonesia
}

\begin{abstract}
Tanjung Formation is one of the major coal-bearing deposit in the Barito Basin, Central Kalimantan. The distribution of total sulfur and ash yield in coal is closely related to the depositional environment. This study was to determine the total sulfur and ash yield and the interpretation of the dynamics of depositional process. Coal seam A and B generally have low to medium ash yield 2.82 to 9.23 (wt.\%, db) and low total sulfur content of $<1(w t . \%, d b)$, except for the 6PLY1 coal sample which has total sulfur content that relatively high at 1.55 (wt.\%, db). Coal samples 5PLY1A, 5PLY1B, 5PLY3, 5PLY5, 6PLY2, 6PLY4, 6PLY5, 6PLY7, and 6PLY9 which have low to medium ash yield and low total sulfur content $<1 \%$ (wt. $\%, \mathrm{db}$ ) are formed in the topogeneous mire (freshwater swamp) in a fluvial environment. The total sulfur content was interpreted to be derived mainly from the parent plant materials. Meanwhile, the 6PLY1 coal sample which has an ash yield of $5.83(\mathrm{wt} . \%, \mathrm{db})$ and total sulfur content of 1.55 (wt.\%, db) formed in topogeneous mire in an environment that is invaded by sea water, and the total sulfur content were interpreted coming from the parent plant materials and the effect of seawater invasion which is rich in sulfate $\left(\mathrm{SO}_{4}\right)$ compounds. It is also supported by the occurrence of syngenetic mineral content (framboidal pyrite) and epigenetic pyrite of 1.23 (vol.\%).
\end{abstract}

Keywords: Barito Basin · Tanjung Formation · Ash · Total sulfur · Syngenetic pyrite.

\section{INTRODUCTION}

Coal is a sedimentary rock that is combustible, which is formed as a result of the lithification process of plant residues deposited in swamp environments and forming peat (Suarez-Ruiz and Crelling, 2008). Kalimantan is one of the islands in Indonesia which is known as the main producer of coal resources. The Barito Basin is one of the main coal-bearing deposits basins which is generally spread in the eastern part of Kalimantan Island (Friederich and van Leeuwen, 2017). In general, coal in the Basin in Kalimantan is divided into two namely Paleogene and Neogen Coal (Friederich et al., 2016; Friederich and van Leeuwen, 2017).

\footnotetext{
*Corresponding author: H. AMIJAYA, Department of Geological Engineering, Universitas Gadjah Mada. Jl. Grafika 2 Yogyakarta, Indonesia. E-mail: hamijaya@gadjahmada.edu
}

Eocene bituminous coal is spread in the sedimentary basin in the southeastern part of Kalimantan Island (especially Barito Basin and Upper Kutai sub-basin), and some in the western part of Kalimantan Island. Eocene bituminous coal typically has low to the moderate ash yield of lesser or equal to $10 \%$ in the Upper Kutai Sub-Basin and reaches more than $15 \%$ in the southeastern part of Borneo, as well as with varying sulfur content (Friederich et al., 2016; Friederich and van Leeuwen, 2017). Meanwhile, Neogen coal generally has low ash and sulfur content. Characteristically, Neogen coal is formed in an ombrogenous peat mires. Highlow volatile bituminous coal of Tanjung Formation in Lemo, Central Kalimantan Province has low ash and total sulfur content (Amrullah, 2009).

Mire is a wetland where the peat accumu- 
lated. It covers all the places where peat is formed, including swamp, bog, fen, moor, muskeg, and peatland (Taylor et al., 1998). Mire can be divided into topogenous mire (marsh, fen, swamps) and ombrogenous mire (raised bog). The formation of peat in topogeneous mire is predominantly influenced by high groundwater levels, while ombrogenous mire (raised bog) is more affected by high rainfall so that the groundwater table is below the peat surface or peat-forming surface (Diessel, 1992; Taylor et al., 1998). In interpreting peat paleodepositional environments, distribution of ash yield and the composition of mineral matters in coal are important parameters.

The distribution and variation of sulfur content are closely related to the coal deposition environment (Diessel, 1992; Taylor et al., 1998; Chou, 2012). Sulfur contained in coal can be derived from the parent plant material and sulfate $\left(\mathrm{SO}_{4}\right)$ compounds in seawater at the time of flooding of the peat swamp. Coal with a sulfur content less than $1 \%$ is classified as low-sulfur coal, while, coal which has a sulfur content of $1 \%$ to $<3 \%$ is classified as medium-sulfur coal, and coal which has a sulfur content of more than 3\% classified as high-sulfur coal (Chou, 2012). The abundance of sulfur content in coal is strongly influenced by invasion or seawater flooding during the process of peat accumulation and after precipitation (Diessel, 1992; Taylor et al., 1998; Chou, 2012).

Ash is an inorganic material or noncombustible residue material after the process of heating or burning coal (Miller, 2005; Thomas, 2002; Speight, 2005; Riddell and Han, 2017). Ash yield is composed by various variations of minerals contained in coal. Minerals matter contained in coal can be in form of detrital minerals, plant-derived minerals, and authigenic minerals (McCabe, 1984). The ash yield in coal generally varies from $5 \%$ to $40 \%$ (Oni and Ehinola, 2017). The distribution and variation of ash yield in coal are greatly affected by the depositional environment in which the coal is formed. This is closely related to the fluctuations in the surface of the water in the mire. The topogenous peat has high nutrient and inorganic materials (mineratrophic). Meanwhile, ombrogenous peat has a very low nutrient supply and inorganic matters (Diessel, 1992; Taylor et al., 1998; McCabe, 1984).

This study aims to analyze the ash and total sulfur content in the Tanjung Formation coal in Sekako, Central Kalimantan to interpreted the dynamics of the peat depositional process.

\section{Regional Setting}

Barito Basin is located in southeastern part of Kalimantan Island (Satyana et al., 2001). The basin is bordered by Meratus Mountain in the eastern part, and western part is bordered by Schwaner Core. Adang Fault separated Barito Basin from Kutai Basin in the northen part, and the basin extended to the Java Sea in the Southern part (Satyana et al., 2001). The Barito Basin was developed in Late Cretaceous to Palo/Eocene that facilitated by the collision of Schwaner Core micro-continent and Peternoster micro-continent (Satyana et al., 1999 in Satyana et al., 2001). At the beginning of the Tertiary, extensional deformation occurs as a result of oblique convergence which then causes rifting and subsidence. This rifting and subsidence process resulted in the formation of horst and graben with northwest-southeast pattern (Satyana and Silitonga, 1994). The rifting process is an accommodation space for the sedimentation of lacustrine and alluvial fans from the lower Tanjung Formation originating from the horst area. As a result of the transgression process that took place in the early Middle Eocene, the rift sediment was changed to fluviodeltaic and marine and was followed by deposition marine shales of the middle and upper Tanjung Formation. The deposition of carbonaceous material was continued until the early Miocene and ended when there was the addition of clastic sediments from the west (Satyana, 1996 in Darman and Sidi, 2000).

Synrift sequence in this basin is composed of Late Paleocene-Middle Eocene sediments namely Lower Tanjung Formation. This formation is composed of sediments of sandstone, siltstone, shales, and conglomerates, with a thin layer of coal. The lower part of this formation is composed of conglomerates and redbeds deposits as part of the fan sediments. The upper part of this sequence is composed of alluvial to lacustrine facies. This sediment characterizes as a major part of the rifting phase, which 
develops as a result of syndepositional faulting (Figure 1). The regional subsidence after the rifting phase in the basin during the Middle Eocene - Early to Middle Miocene, during this time the sediment materials deposition occurred from the upper of the lower part of Tanjung Formation, Upper Tanjung Formation, and Berai Formation, as the sediments from the transgressive phase. The change in sediment characteristics is very clear in the synrift and postrift sequences. Based on well drilling data, the lower part facies and its thickness changes is local which indicates rift-infill, and the upper sequences of the sediments are a regional occurrence which indicated that they are more influenced by the irregularity horst and graben terrain (Satyana and Silitonga, 1994).

\section{Methodology}

\subsection{Sample}

Coal samples were taken from the coal seam $\mathrm{A}$ and B of Tanjung Formation at the PT. Suprabari Mapanindo Mineral (PT. SMM) in Sekako area, North Barito Regency, Central Kalimantan Province (Figure 2). Coal seams that used are coal seam A and coal seam B, and coal samples used for laboratory analysis were 10 samples.

\subsection{Method}

Coal samples were taken using channel sampling method and taken ply by ply. Plies were determined based on their lithotype (see Figure 3). Analysis of ash and total sulfur content was carried out at PT. Sucofindo in Surabaya. Ash yield analysis refered to ASTM D 3174 and total sulfur content analysis was conducting according to ASTM D 4239. Analysis of mineral matter content was carried out using reflected microscope at the Optical Geology Laboratory, Universitas Gadjah Mada, Yogyakarta. The analysis was conducted according to ASTM D 2799 based on 550 point counting.

\section{Results AND Discussion}

\subsection{Coal lithotype, distribution of ash and to- tal sulfur content}

The characteristics of coal seam A and B are presented in Figure 3 and Table 1. Coal seam A has a thickness of approximately $1.5 \mathrm{~m}$ and it is predominantly composed of bright coals
Table 1: Total sulfur and ash yield of coal seam A dan B of Tanjung Formation in Sekako area.

\begin{tabular}{|c|l|c|c|}
\hline No & $\begin{array}{c}\text { Coal } \\
\text { Samples }\end{array}$ & $\begin{array}{c}\text { Ash (wt.\% } \\
\mathbf{d b})\end{array}$ & $\begin{array}{c}\text { Total } \\
\text { Sulfur } \\
\text { (wt.\% db) }\end{array}$ \\
\hline 1 & 5PLY1A & 4 & 0.3 \\
\hline 2 & 5PLY1B & 3.41 & 0.39 \\
\hline 3 & 5PLY3 & 8.98 & 0.38 \\
\hline 4 & 5PLY5 & 9.23 & 0.3 \\
\hline 5 & 6PLY1 & 5.83 & 1.55 \\
\hline 6 & 6PLY2 & 2.82 & 0.89 \\
\hline 7 & 6PLY4 & 3.43 & 0.77 \\
\hline 8 & 6PLY5 & 4.75 & 0.59 \\
\hline 9 & 6PLY7 & 4.34 & 0.47 \\
\hline 10 & 6PLY9 & 4.05 & 0.53 \\
\hline
\end{tabular}

Note: weight percentage (wt.\%), dry basis $(\mathrm{db})$

lithotypes with claystone layers as the inorganic partings. The coal has an ash yield of $3.41-9.23$ $(\mathrm{wt} . \%, \mathrm{db})$ and the total sulfur content of 0.30 0.38 (wt.\%, db). Two samples of coal seam 5.1 have more than 5 (wt.\%, db) ash yield found in 5PLY3 and 5PLY5 coal samples (Table 1 and Figure 3). Meanwhile, Coal seam 6 has a thickness of approximately $3 \mathrm{~m}$, and it is predominantly composed by bright coals and banded bright coals. There are also claystones layers as inorganic parting. The coal has an ash yield of $2.82-5.83$ (wt.\%, db) and total sulfur of 0.47 1.55 (wt.\%, db).

\subsection{The interpretation of paleodepositional environmental}

Modern dome peat in the tropical forest generally has very low ash yield $(<1 \%)$ and low sulfur content (Esterle et al., 1989; Cameron et al., 1989; Calder et al., 1991). Peat formed on topogeneous peat or planar peat generally has a thinner thickness and has more inorganic split or inorganic parting compared to peat formed on the ombrogeneous peat (Cohen and Stack, 1996).

Coal which has a low sulfur content $(<1 \%)$ are generally assumed to have sulfur content which comes from the parent plant material. Meanwhile, coal which has medium sulfur content (1 
Total Sulfur And Ash Yield of TANJung Formation COAl in SEKAKo, BARIto BASIN

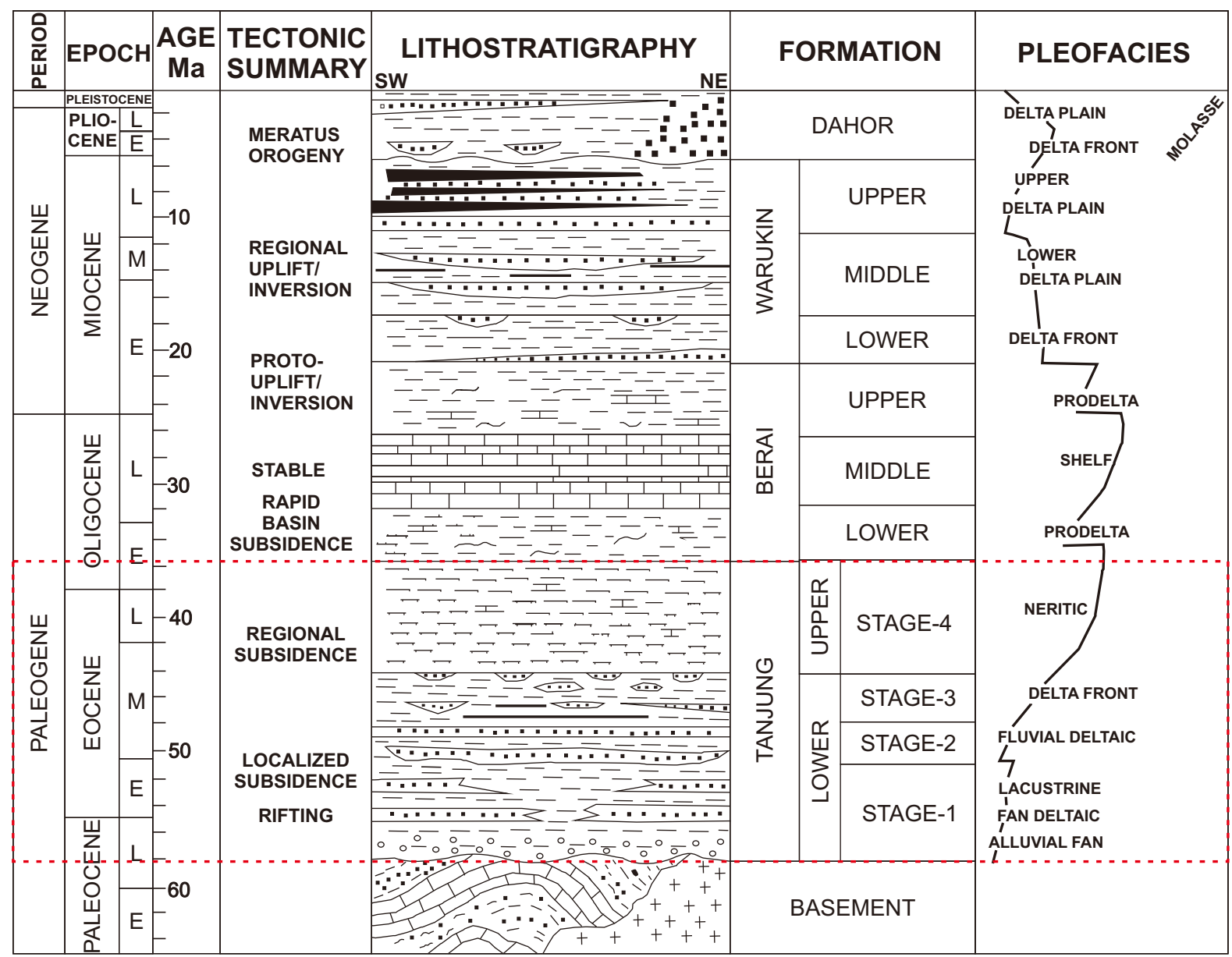

Figure 1: The stratigraphic of the Barito Basin that showing the formation, paleofacies, and the tectonic episode (Satyana dan Silitonga, 1994).

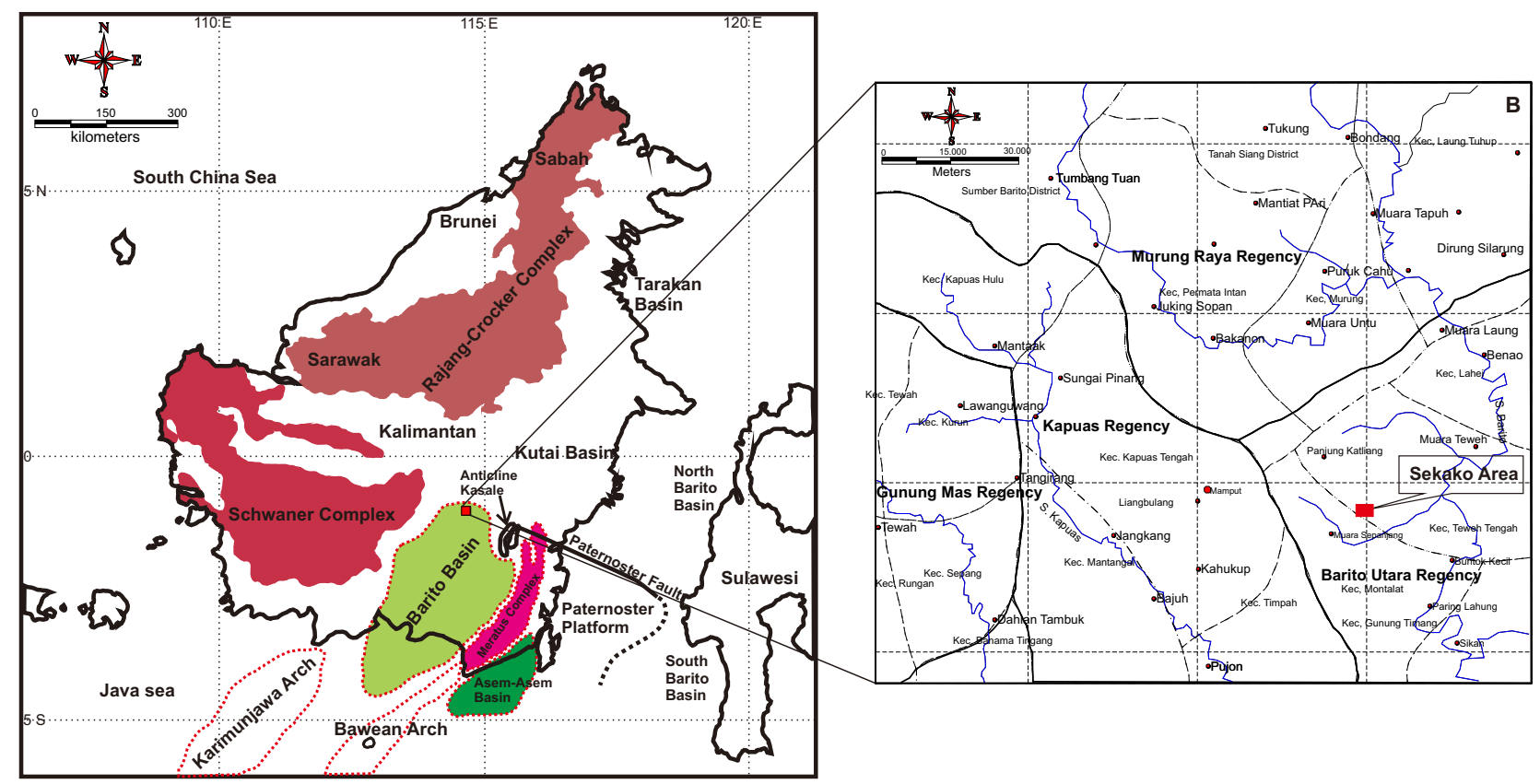

Figure 2: a. Physiography of Kalimantan Island and the study area location showed on the red rectangle, and $b$. Study area location map that showed by red rectangle (modification from Witts et al., 2012 and administrative map is from bnpb.go.id). 
WIRANATA et al.

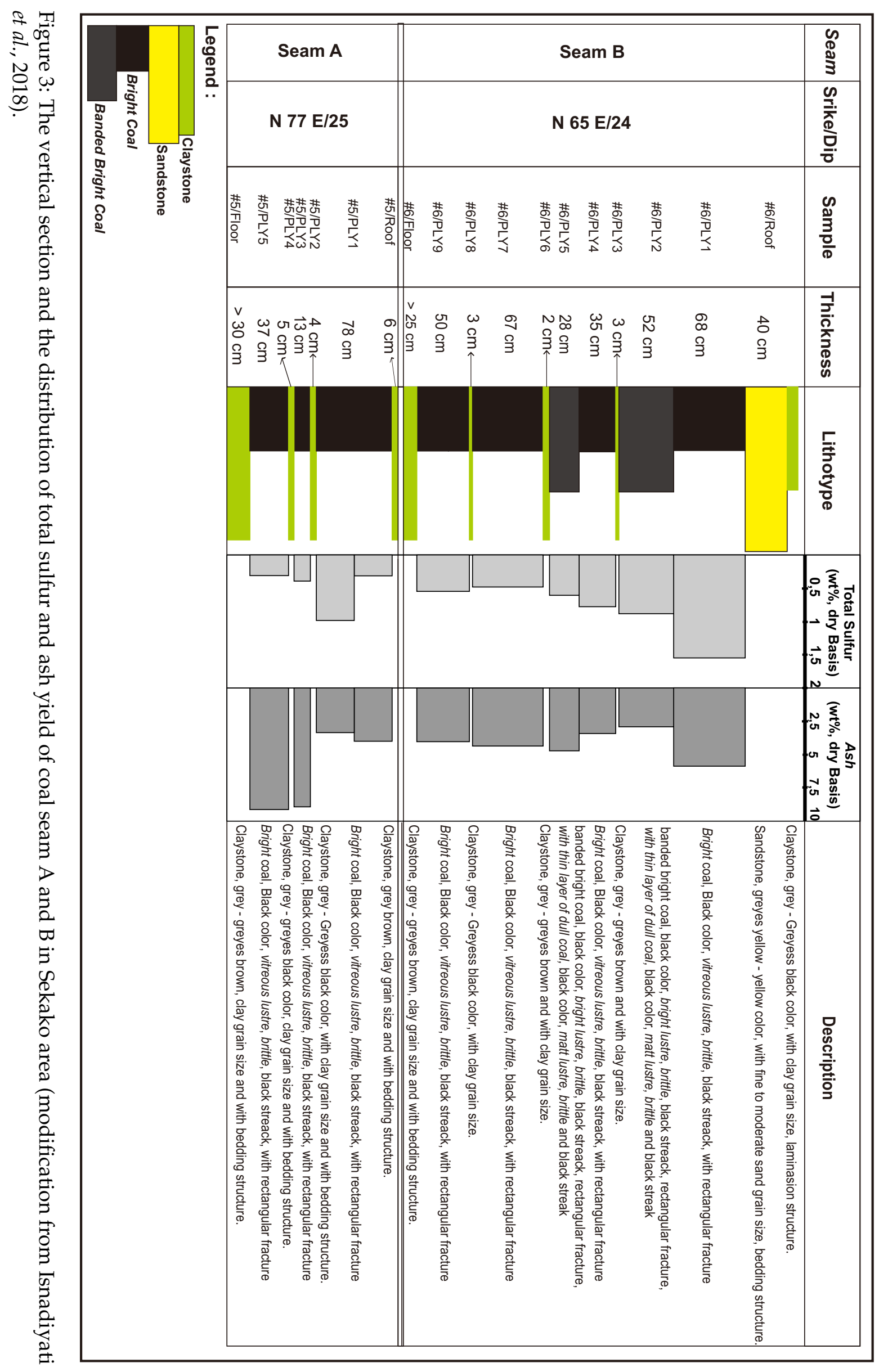


to $<3 \%$ ) and high sulfur content equal or more than $3 \%$, the sulfur content comes from the parent plant material and comes from the influence of seawater invasion which is rich in compound content sulfate $\left(\mathrm{SO}_{4}\right)$. In various cases, coal with low sulfur content $(<1 \%)$ is generally formed in fluvial environments and coal which has a high sulfur content formed in the environment is affected by the presence of seawater invasion (Chou, 2012).

Widodo et al. (2010) studied the coal of Pulau Balang Formation in Sebulu and Central Busang in the Kutai Basin have high ash and sulfur content, and also high pyrite mineral content. Pyrite minerals are generally syngenetic and epigenetic pyrite and interpreted to be formed in the topogeneous mire. Meanwhile, the Embalut coal from the Balikpapan Formation has lower sulfur content of $<1 \%$ and very low pyrite minerals interpreted to be formed in the ombrogeneous mire.

Based on the coal lithotype characteristics, the coal seam A and B of Tanjung Formation in Sekako is interpreted to form in the telmatic wet forest paleomire swamp (Isnadiyati et al., 2018). Coal seam A has low to moderate ash yield 3.41-9.23 (wt.\%, db) and low total sulfur content $<1 \%$. This coal seam is interpreted to be formed in the topogenous mire (mineratrophic) which has a high water table and is rich in nutrient or inorganic material content. The high water level makes the peat always flooded, and facilitates detrital mineral sediment material transported into the mire where coal is formed by water or wind. Inorganic material or mineral matter contained in coal not only comes from detrital minerals but can also be formed from plant-derived minerals and authigenic minerals (McCabe, 1984).

However, even though coal seam A is deposited and formed on topogenous mire which is always inundated, the coal has a low total sulfur content of $<1 \%(w t . \%, d b)$. This shows that coal seam A is formed and deposited on freshwater peat swamp and there is no invasion or flooding of seawater. The sulfur content contained in coal can be interpreted from an organic material or the parent plant material or sulfur containing mineral authigenetically.

Coal seam B of Tanjung Formation in Sekako area has moderate - high ash yield, which ranges from 2.82 to 5.83 (wt.\%, db). Meanwhile, the coal has a total sulfur content of generally $<1$ (wt.\%, db), except for the coal sample 6PLY1 which has medium sulfur total content (moderate) which is 1.55 (wt.\%, db). The coal is interpreted to be formed in topogenous material which is rich in nutrient content and inorganic materials. The mire always flooded with high water levels so that detrital minerals or mineral matter enters the mire which is facilitated by wind or water media.

To the upward position (6PLY9, 6PLY7, PLY5, 6PLY4, and 6PLY2), it is interpreted that they were formed in the topogenous mire which is in the freshwater telmatic wet forest swamp. This may cause moderate to high ash yield of coal. The coal is probably formed without invasion or seawater flooding so it has a low total sulfur content of $<1 \%(w t . \%, d b)$. The low sulfur content is interpreted to be formed from the parent plant material. Low sulfur content is probably also an indication that the coal was formed in the fluvial associated subenvironment. During the last deposition phase of the banded bright coals (6PLY2) level increased which cause the mire was invaded or flooded by sea water. At the same time, the peat precursor of bright coal lithotype (6PLY1) was formed. The 6PLY1 coal sample has relatively high ash and total sulfur content compared to other samples (5.83 wt.\%, $\mathrm{db}$ and $1.55 \mathrm{wt} . \%, \mathrm{db})$.

The high total sulfur content in the 6PLY1 coal sample is interpreted to be formed both from the parent plant material and influence of sea water which is rich in sulfate compounds. This is also supported by the results of mineral matter analysis which shows that bright coal (6PLY1) has a pyrite content of 1.23 (vol.\%) and consists of syngenetic minerals and epigenetic pyrite (Figure 4). The syngenetic pyrite mineral is also a sign of the invasion or flooding of seawater during its formation. Syngenetic pyrite is formed because of biochemical processes by anaerobic microorganisms or bacteria against sulfate compounds $\left(\mathrm{SO}_{4}\right)$. This will produces $\mathrm{H}_{2} \mathrm{~S}$ compounds which then react with iron $\left(\mathrm{Fe}^{2+}\right)$ from detrital mineral to form framboidal pyrite $\left(\mathrm{FeS}_{2}\right)$ (Ward, 2002). The framboidal pyrite mineral is generally polycrystalline in form and has a spherical shape.

After that, there was a decline in sea level 
WIRANATA et al.
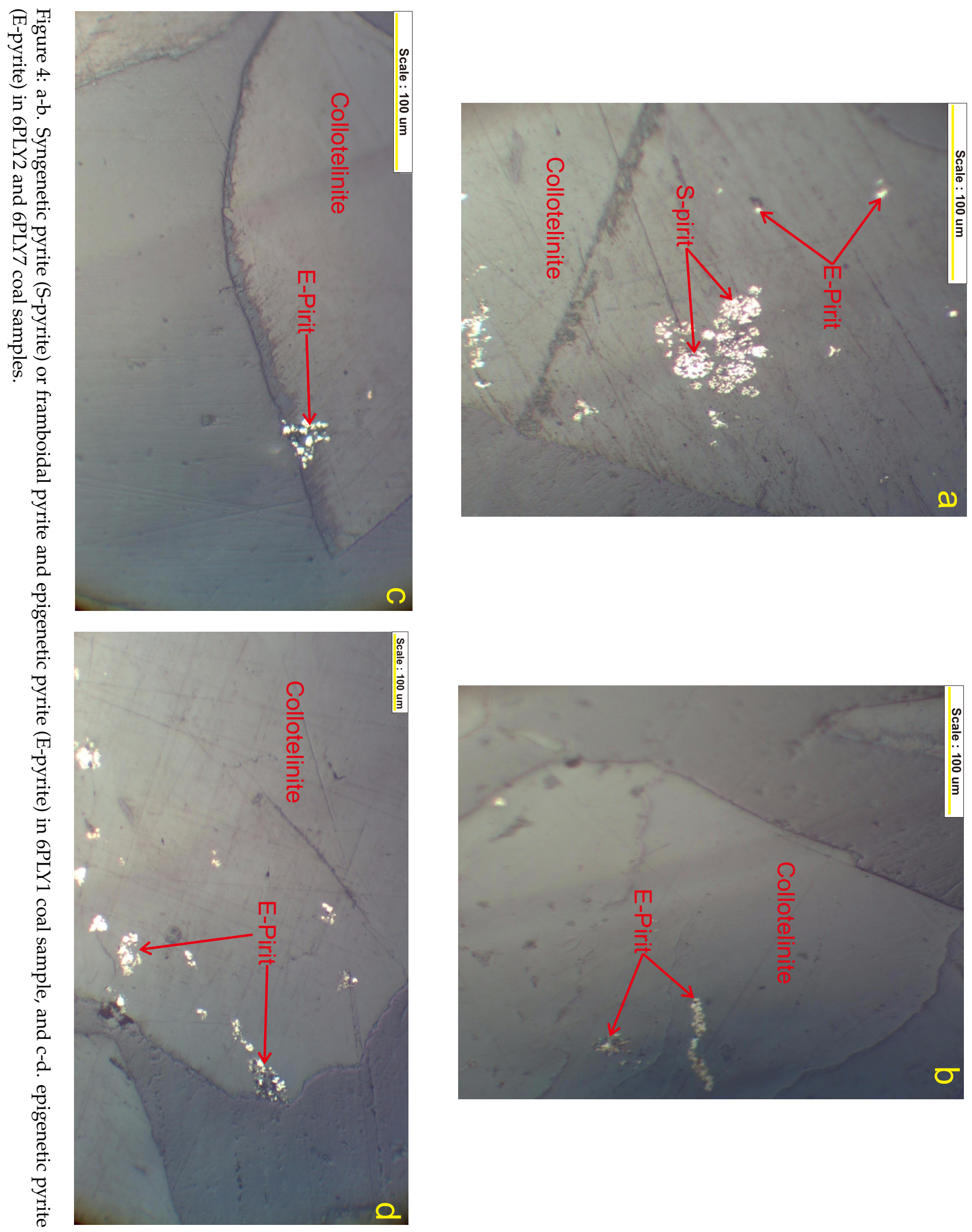
which caused change in the depositional environment to be more shallow. It is also characterized by the deposition of fine - medium sandstones (Figure 3 and Figure 5) above bright banded coal lithotypes (6PLY1). Furthermore, Isnadiyati et al., (2018) interpreted that one of the coal seam $\mathrm{A}$ in this area was formed by 3 different paleopeat bodies. This successive development of peat are characterized by the presence of two claystone layers as inorganic parting/inorganic split. Coal seam B was interpreted to be formed on 4 different paleopeat bodies which are characterized by the presence of three claystone layers as the inorganic parting. It also shows that coal seam A and B are formed in inundated mire. This mire had high water table and fluctuation occurred. The water table fluctuation caused deposition of inorganic parting which then followed by reinitiation of paleopeat. The summary of the dynamic change of depositional condition during the formation of coal seam A and seam coal B is presented in Figure 5.

\section{CONCLUSION}

Coal seam A and seam B of Tanjung Formation in Sekako have thicknesses of $1.5 \mathrm{~m}$ and 3 $\mathrm{m}$ respectively and is are predominantly composed by of bright coals and banded bright coals. The coal generally has medium-high ash yield of 2.82 to 9.23 (wt.\%, db) and low sulfur content $<1$ (wt. \%, db), except for the 6PLY1 coal sample which has a high sulfur content which is 1 . 55 (wt.\%, db). Coal samples (5PLY1A, 5PLY1B, 5PLY3, 5PLY5, 6PLY2, 6PLY4, 6PLY5, 6PLY7, and 6PLY9) which have medium to high ash yield and low sulfur content $<1 \%$ are interpreted to be formed in the topogenous mire (freshwater swamp) in a fluvial environment. The sulfur content is mainly related with the original sulfur in the parent material and some sulfur containing authigenic mineral which was formed during the peatification. Meanwhile the 6PLY1 coal sample which has an ash yield of $5.83(w t . \%, d b)$ and total sulfur content > $1 \%(\mathrm{wt} . \%, \mathrm{db})$ indicates a higher ash and sulfur content which was contributed by the presence of invasion or flooding by seawater rich in sulfate $\left(\mathrm{SO}_{4}\right)$ compounds in the topogeneous mire in limnic environments. Framboidal pyrite minerals found within the coal samples are indicator of this phenomenon.

\section{ACKNOWLEDGEMENTS}

Authors thank PT. Suprabari Mapanindo Mineral (PT. SMM) for permission to take coal samples. This work was partly funded by the Ministry of Research and Higher Education under PDUPT UGM.

\section{REFERENCES}

Amarullah, D. (2009) Suatu Pemikiran Untuk Memanfaatkan Potensi Batubara Formasi Tanjung Di Daerah Lemo Kalimantan Tengah Sebagai Kokas. Kelompok Program Penelitian Energi Fosil, Pusat Sumber Daya Geologi, Bandung. v. 4. p. 1-11.

Amijaya, H., dan Litke, R. (2005) Microfacies and Depositional Environment of Tertiary Tanjung Enim Low Rank Coal, South Sumatra Basin, Indonesia. International Journal of Coal Geology, v. 6. p. 197-221.

ASTM (1977) Gaseous Fuel; Coal and Coke; Atmospheric Anlysis. American Society For Testing and Materials. v. 26. p. 429.

American Society for Testing and Materials (ASTM) D 3172 (2013) Standard Practice for Proximate Analysis of Coal and Coke.

American Society for Testing and Materials (ASTM) D 4239 (2018. Standard Test Methods for Sulfur in the Analysis Sample of Coal and Coke Using High-Temperature Tube Furnace Combustion.

Badan Nasional Penanggulangan Bencana (2009) Peta Pulau Kalimantan: geospasial.bnpb.go.id (diakses pada Mei 2018).

Belkin, H.E., Tewalt, S.J., Hower, J.C., Stucker, J.D., O'Keefe, J.M.K. (2009) Geochemistry and petrology of selected coal samples from Sumatra, Kalimantan, Sulawesi and Papua, Indonesia, International Journal of Coal Geology, v.77. p. 260-268.

Calder, J.H., Gibling, M.R., Mukhopadhyay, P.K. (1991) Peat Formation in A Westphalian B Piedmont Setting, Cumberland Basin, Nova Scotia : Implications for The Maceral-Based Interpretation of Rheotrophic and Raised Paleomires. Bulletin Soc Geology. v. 162. No. 2. p. 283-298.

Cameron, C.C., Esterle, J.S., Palmer, C.A. (1989) The Geology, Botany, and Chemistry of Selected Peat-Forming Environments From Temperate and Tropical Latitudes. International Journal of Coal Geology, Elsevier. v. 12. p. 105-156.

Chou, C.L. (2012) Sulfur in Caols: A Review of Geochemistry and Origins. International Journal of Coal Geology, v. 100. p. 1-13.

Cohen, A.D., and Stack, E.M. (1996) Some Observations Regarding The Potential Effect of Doming of Tropical Peat Deposits On The Composition of 
WIRANATA et al.

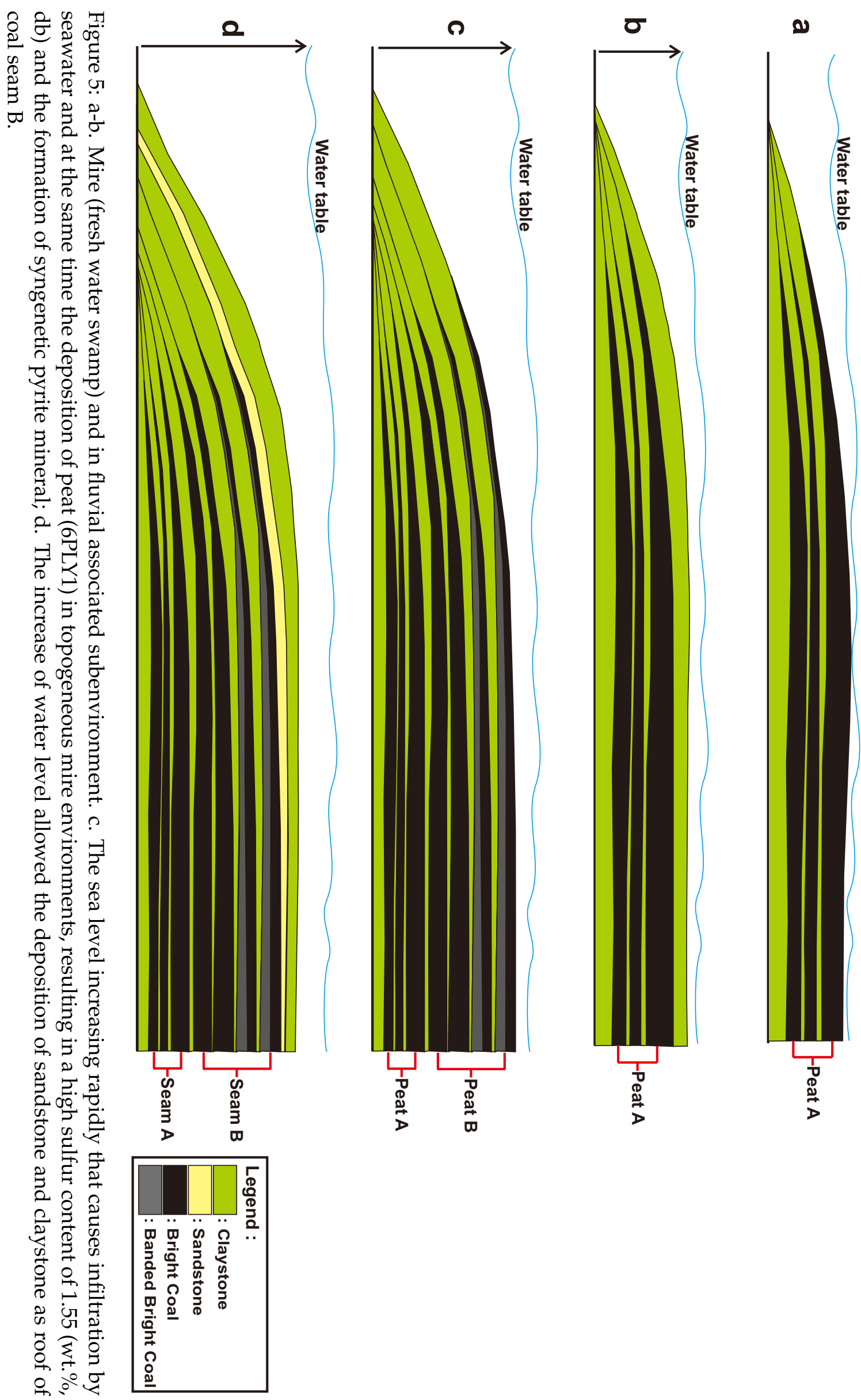


Coal Beds. International Journal of Coal Geology,elsevier. v. 29. p. 39-65.

Darman, H., Sidi, F.H. (2000) An Outline of The Geology of Indonesia. Ikatan Ahli Geologi Indonesia, Jakarta, $254 \mathrm{p}$.

Diessel, C.F.K. (1992) Coal-Bearing Depositional System. Thompson Press (India) Ltd., New Delhi. $679 \mathrm{p}$.

Esterle, J.S., Ferm, J.C., Yiu-Liong, T. (1989) A Test for The Analogy of Tropical Domed Peat Deposits To "Dilling Up" Sequence in Coal Beds - Preliminary Results. Organic Geochemistry. v. 14. No. 3. p. 333-342.

Friederich, M.C., Moore, T.M., Flores, R.M. (2016) A Regional Review And New Insights Into SE Asian Cenozoic Coal-Bearing Sediments: Why Does Indonesia Have Such Extensive Coal Deposits?. International Journal of Coal Geology, v. 166. p. 235.

Friederich, M.C., dan van Leeuwen, T. (2017) A Review of The History of Coal Exploration, Discovery and Production in Indonesia: The Interplay of Legal Framework, Coal Geology and Exploration Strategy. International Journal of Coal Geology, v. 178, p. 56-73.

Isnadiyati, O.F., Wiranata, B., Perdana, A.R., Tanggara, D.N.S.P., Amijaya, H., (2018) Iterpretasi Stacked Mire Sequence Berdasarkan Litotipe Pada Batubara Coking Formasi Tanjung Di Daerah Sekako, Kalimantan Tengah. Seminar Nasional Kebumian, Yogyakarta. v. 11, p. 31.

Lamberson, M.N., Bustin, R.M., Kalkreuth, W. (1991) Lithotype (maceral) Composition and Variation As Correlated With Paleo-Wetland Environments, Gates Formation, Northeastern British Columbia, Canada. International Journal of Coal Geology, v. 18. p. 87-124.

McCabe, P.J. (1984) Depositional Environments of Coal and Coal-Bearing Strata. The International Association of Sedimentologists, v. 7. p. 13-42.

Oni, O.S., dan Ehinola, A.O., (2017) Estimation and Assesment of Free Swelling Index and Some Petrographic Properties From Chemical Analysis of Coals Across River Niger. Petroleum and Coal. v. 59 (30). p. 273-287.

Riddell, J., dan Han, T. (2017) Ash Chwmistry
Database For British Columbia Rocky Mountain Bituminous Coals. British Columbia Geological Survey. v. 10. 15 p.

Ryemshak, S.A., dan Jauro, A. (2013) Proximate analysis, Rheological Properties and Technological Application of Some Nigerian Coals. International Journal of Industrial Chemistry (IJIC). v. 4. p. 1-7.

Satyana, A.H., and Silitonga, P.D. (1994) Tectonic reversal in East Barito Basin, South Kalimantan: consideration of the types of inversion structures and petroleum system significance: in Proceedings of the IPA 23rd Annual Convention. p. 57-74.

Satyana, A.H., Eka, M.P., Imron, M. (2001) Eocene Coals of The Barito Basin, Southeast Kalimantan: Sequence Stratigraphic Framework and Potential for Sources of Oil : Berita Sedimentologi. v. 3. No. 17. p. 1-15.

Soetrisno, Supriatna, S., Rustandi, E., Sanyoto, P., Hasan, K. (1994) Geological Map of The Buntok Quadrangle, Kalimantan. Geological Research and Development Center. 1 p.

Suarez Ruiz, I., Crelling, C.J. (2008) Applied Coal Petrology. Elsevier. 388 p.

Taylor, G.H., Teichmuller, M., Davis, A., Diessel, C.F.K., Littke, R., Robert, P. (1998) Organic Petrology. Gebruder Borntraeger, Stuttgart. 704 p.

Thomas, L. (2002) Coal Geology First Edition. John Wiley \& Sons, Ltd, West Sussex, United Kingdom. $384 \mathrm{p}$.

Ward, C.R. (2002) Analysis and Significance of Mineral Matter in Coal Seams. International Journal of Coal Geology, v. 50. p. 135-168.

Widodo, S., Oschmann, W., Bechtel, A., Sachsenhofer, R.F., Anggayana, K., Puettmann, W. (2010) Distribution of Sulfur and Pyrite in Coal Seams From Kutai Basin (East Kalimantan Indonesia): Implications For Paleoenvironmental Conditions. International Journal of Coal Geology, v. 81. p. 151-162.

Witts, D., Hall, R., Nichols, G., dan Morley, R. (2012) A New Depositional and Provenance Model For The Tanjung Formation, Barito Basin, SE Kalimantan, Indonesia. Journal of Asia Earth Science, v. 56. p. $77-104$. 